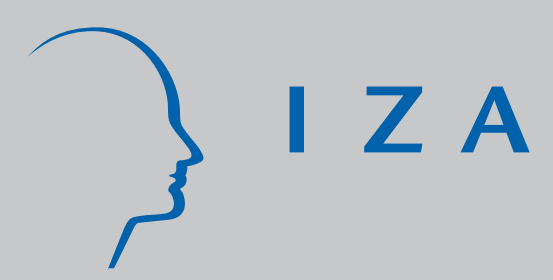

IZA DP No. 5886

Re-Visiting the Easterlin Hypothesis:

Marriage in the U.S. 1968-2010

Diane J. Macunovich

July 2011

Forschungsinstitut

zur Zukunft der Arbeit

Institute for the Study of Labor 


\title{
Re-Visiting the Easterlin Hypothesis: Marriage in the U.S. 1968-2010
}

\author{
Diane J. Macunovich \\ University of Redlands \\ and IZA
}

\section{Discussion Paper No. 5886}

July 2011

\author{
IZA \\ P.O. Box 7240 \\ 53072 Bonn \\ Germany \\ Phone: +49-228-3894-0 \\ Fax: +49-228-3894-180 \\ E-mail: iza@iza.org
}

Any opinions expressed here are those of the author(s) and not those of IZA. Research published in this series may include views on policy, but the institute itself takes no institutional policy positions.

The Institute for the Study of Labor (IZA) in Bonn is a local and virtual international research center and a place of communication between science, politics and business. IZA is an independent nonprofit organization supported by Deutsche Post Foundation. The center is associated with the University of Bonn and offers a stimulating research environment through its international network, workshops and conferences, data service, project support, research visits and doctoral program. IZA engages in (i) original and internationally competitive research in all fields of labor economics, (ii) development of policy concepts, and (iii) dissemination of research results and concepts to the interested public.

IZA Discussion Papers often represent preliminary work and are circulated to encourage discussion. Citation of such a paper should account for its provisional character. A revised version may be available directly from the author. 
IZA Discussion Paper No. 5886

July 2011

\section{ABSTRACT \\ Re-Visiting the Easterlin Hypothesis: Marriage in the U.S. 1968-2010}

This study tests the effect of relative income - younger people's earning potential relative to their aspirations, as approximated by older families' income - on the proportions married, by sex, in the first fifteen years out of school. It finds that relative income has become a better measure to use, than relative cohort size, because of a disconnect that has developed between the two as a result of rising female labor force participation among older women that has inflated older families' income faster than older men's earnings. The results are highly supportive of the Easterlin relative income hypothesis, finding a dominant negative effect of older family income that extends due to postponement effects even into groups 11-15 years out of school. But in addition it finds a strong but changing effect of the female wage: positive among women 0-5 years out of school, although slowly declining over time, but negative among the older women with a dominant positive time trend that has produced a positive effect in the last decade. The elasticity with respect to older family income suggests that it was responsible for $16 \%$ of the observed decline in the proportion of women $0-5$ years out of school who were married, and $23 \%$ of the proportion for the men in the same group. There is in addition, however, a very strong negative time trend.

JEL Classification: J12

Keywords: marriage, relative income, relative cohort size, Easterlin hypothesis, marriage squeeze

Corresponding author:

Diane J. Macunovich

Department of Economics

University of Redlands

Redlands, CA 92346

USA

E-mail: diane_macunovich@redlands.edu 
Among those 0-15 years out of school, marriage rates in the U.S have been declining steadily for all groups with less than sixteen years of education since at least the mid-1960s. The declines have been particularly steep for those with twelve or fewer years of schooling (see Figures 1 and 2). For women with more than sixteen years, however, rates have actually been on the increase since about 1990, and they have remained fairly steady over the study period for men with more than sixteen years of schooling. What has accounted for these patterns? Increasing levels of cohabitation of course account for a good deal of the declines that have been observed. But male wages - usually found to have a positive effect on marriage - have increased significantly since the early 1990s (see Figure 3). Female wages have increased as well (Figure 4) - although there have been mixed findings regarding their influence ${ }^{1}$.

Countering any positive effects of increasing economic prospects for young people, however, has been a strong negative effect of parental income, as first hypothesized by Richard Easterlin (1978). Easterlin postulated a systematic shift in preferences resulting from the fact that each successive generation, under economic development, experiences a successively higher parental standard of living. "In effect, a... 'subsistence level' constraint is added to the analysis of [marriage behavior] along with the budget line and production constraints." (Easterlin, 1978, and Ahlburg, 1984). Because of this 'subsistence level' constraint, economic or demographic fluctuations could cause periodic changes in marriage rates.

According to the Easterlin theory, a large birth cohort meets unfavorable labor market conditions which reduce the earning potential of young males relative to their aspirations. In an attempt to close the gap between income and aspirations, members of such a cohort will tend to make a number of adjustments including increased female labor force participation and delayed/reduced marriage and childbearing. In addition, because young women in large cohorts will anticipate higher levels of labor force participation, they will tend to enroll in college at increased rates. In this formulation the driving force behind both increased female labor force participation and enrollments, and reduced marriage and fertility rates, is the

\footnotetext{
${ }^{1}$ Only the starting wage for women was used in the analysis, because of the endogeneity of women's observed wage.
} 
desire of a large cohort to improve relative economic status, with parental income as the measure of that cohort's material aspirations.

The historic pattern of older family income is displayed in Figure 5. Older family income is defined here to be consistent with Easterlin's hypothesis: the income of families with head of either sex aged 45-54. Also shown there is the historic pattern of earnings of men with 25-34 years of work experience roughly, men aged 45-54. The gap between these two curves indicates the magnitude of the effect of rising female labor force participation - the growth in two-earner families: the gap has widened significantly over the study period. Over all education levels, fathers' earnings increased by only $2.5 \%$ between 1970 and 2010, from $\$ 52,320$ to $\$ 53,620$ in 2009 dollars, whereas family income increased by $30.4 \%$ during the same period, from $\$ 69,408$ to $\$ 90,522$. Between 1968 and 2010, older familes' income increased by $44.6 \%$ while fathers' income increased by only $12.7 \%$. As a result, young people's relative income has not recovered since the peak of the boom, as their wages have. Their relative income - their wage relative to older family income, measured in thousands - is displayed in Figures 7 and 8.

\section{Literature Review}

Although not always looking specifically at the Easterlin hypothesis, there have been a number of studies that have examined the effect of parental characteristics on their adult children's marriage propensities. These have tended to use parental education and occupation as the explanatory variables, rather than actual income, and have found mixed effects, although in general the effects of higher levels of education and occupation for the parents have tended to be associated with lower propensities to marry. Pollard and Wu (1998) found a negative effect of parental education on young women's marriage propensity, and Oppenheimer (1997) found this effect for both men and women. Waite and Spitze (1981) found mixed effects, depending on age, with a negative effect of mother's education for women aged 16-17 but a small positive effect at age 24-25. Father's education had a negative effect at all ages. Sweeney (2002) found a mild negative effect of mother's education for a later cohort (born 1961-65), but an insignificant effect for 
a younger cohort (1950-54). He found an insignificant effect of father's occupation. Goldscheider and Waite (1986) found a negative effect of parental education for both men and women, but a negative effect of occupation only for men.

One study used actual parental income for individuals who graduated from Wisconsin high schools in 1957 (MacDonald and Rindfuss, 1981), specifically to test the Easterlin Hypothesis, and found no support for it. Macunovich (2002) found support for the hypothesis, however, using parental income at a more aggregated level. In related work, Watson and McLanahan (2009) found significant effects of an MSAlevel race-and education-specific measure of "ideal" income. They found that for men who fell short of the ideal there was a rapidly increasing propensity to marry as they approached the ideal, up to a ratio of 1.0 to 1.3 , but that this effect became negligible as individuals exceeded the ideal. To some extent related to this, Loughran (2002) found that increasing male wage inequality contributes significantly to observed declines in women's propensity to marry - which they attributed to increased search costs - and Gould and Paserman (2003) found that increased male wage inequality accounted for one-third of the decline.

There has been a great deal more work focused on the effects of male and female economic factors on the propensity to marry, however, with a virtually unanimous finding of a positive effect of male income for men, and usually for women (Burgess and Propper, 2003; Xi, Raymo, Goyette and Thornton, 2003; Sweeney, 2002; Blau and Kahn, 2000; Sassler and Schoeni, 1999; Oppenheimer, Kalmijn and Lim, 1997; Smock and Manning, 1997; Lloyd and South, 1996; Cooney and Hogan, 1991; Teachman, Polonko and Leigh, 1987; Goldscheider and Waite, 1986).

The results for women's economic status tend to be much more mixed, however, and nuanced. Oppenheimer (1997) found that more aggregate cross sectional studies, like that of McLanahan and Casper (1995), almost universally found negative effects of economic opportunities on a woman's propensity to marry, but that individual-level longitudinal analyses have not supported the idea that 
increased economic opportunities cause women to postpone or forego marriage. She attributed the negative results in part to a problem of establishing causality: does female labor force participation affect marriage, or vice versa? But Sweeney (2002) performed a cohort analysis, comparing the 1950-54 early Boom cohort with the later 1961-65 cohort, and found a reversal in the effect over time, with the early cohort experiencing a negative effect of women's economic opportunities, but the later cohort experiencing a positive effect. He found that women with sixteen years of schooling had a 52\% higher odds of marrying than women with less than twelve years. Similarly, Qian and Preston (1993) found that the propensity to marry among college educated women increased between 1979 and 1987. These findings accord with Oppenheimer's earlier hypothesis (1988), that over time women's increased earning power would make them more attractive as potential partners.

And finally, another topic that has been discussed with regard to marriage propensities, perhaps first suggested by Easterlin (1961) and then popularized by Guttentag and Secord (1983), is the sex ratio, or "marriage squeeze" variable. This arises from the idea that if there are too many men relative to the number of women, men will find it harder to find a partner, whereas women will have an easier time, since there will be an excess demand for their skills in household production. The theory was set out by Grossbard-Shechtman in 1984, and tested in 1985, finding a significant positive effect for women. Angrist (2002) used immigrant flows to examine marriage patterns in second generation immigrants, and found a strong positive effect of the sex ratio for women, but a surprising smaller positive effect for men, as well. The national pattern of the "marriage squeeze" variable is presented in Figure 6. It is constructed as a 22-year lag of the ratio of the number of births in year $t$ to the number in year $t-1-$ on the assumption of a one-year difference between men and women at age of marriage. It is used at the national level since local levels could be influenced by migration from state to state in response to economic or marriage market conditions. The strange peak in the center of the graph is due to the temporary increase and then decrease in the number of births that occurred between 1968 and 1970 - possibly a result of the deferments given to fathers during the Vietnam War. 


\section{Measures of Relative Income ${ }^{2}$}

Easterlin (1987) has characterized his concept of relative income as (earnings potential)/(material aspirations). He operationalized this measure using "the recent income experience of a young man relative to the past income of the young man's parents." The concept is hypothesized to operate at the micro level; that is, young adults are assumed to set their desired standard of living based on the standard of living experienced in their own parents' homes.

However, there has been little research on the formation of material aspirations, so that the formulation of a relative income measure at the micro level is fraught with hazards. What is an appropriate relative income measure for an unmarried woman? In general we lack micro datasets which provide information on first and second generation income and marital behavior.

Thus any tests of the Easterlin hypothesis at the micro level have either used gross proxies for the relative income measure (such as occupational data or responses to questions such as "How well-off are you?"-see MacDonald and Rindfuss, 1978), In addition, micro level formulations treat aspirations as being only a function of parental income, whereas it is likely that peer groups and other larger-scale social phenomena also operate on individual aspirations.

Such problems do not occur in more aggregate analyses. At the aggregate level we don't have to associate individuals with their own parents, but rather a young generation with its parental generation. We can use average household income in the parental generation as a measure of the average desired standard of living for both males and females in the younger generation, and this measure will better approximate both parental and other influences on a cohort's aspirations.

\footnotetext{
${ }^{2}$ This section is drawn largely from Macunovich (1996).
} 
Macunovich (1996, 1998b) used U.S. national time series data for tests of fertility using Easterlin's relative income model, but Macunovich (2002) used more disaggregated data for both fertility and marital behavior, and this study follows suit - at the level of year-state-race-education-experience specific cells. It is assumed that fertility among individuals in the first fifteen years out of school will respond to parental income measured at their corresponding year-state-race-education specific level.

\section{Data and Methodology}

The data are taken from the March Current Population Survey (CPS) for the years 1968-2010, as made uniform in CPS Utilities. All individual-level data has been aggregated into sex-year-state-raceeducation-experience cells ${ }^{3}$. Only currently unenrolled individuals were included in the analyses, and CPS weights were used in all cases, but they were normalized to sum to one in each year, in order to avoid unduly weighting any one year. Analysis has been performed using Stata's "robust" OLS option that removes outliers ${ }^{4}$.

The assumption in all of these analyses is that the relative income comparison so difficult to quantify at the individual level using available data sources can be approximated using regional year-race-education level average parental income measures. Thus it is assumed that, all other factors held constant, young adults in a given year-state-race-education group with high parental income will feel relatively poorer than young adults where parental income in such a group is lower.

The marriage indicator used in the analysis is the proportion of individuals in a given year-state-raceeducation-"years out of school" cell who are currently married. Since the proportions would be highly correlated with years out of school, dummies were included based on years out of school, which should

\footnotetext{
${ }^{3}$ Experience is measured as years out of school, using age-6-years of education. Only non-enrolled individuals are included in the analyses. The state groupings differ over the period, with 30 groups in the 1968-72 period, 23 in the 1973-76 period, and 51 from 1977 onward (including the District of Columbia). In all regressions, dummies for the 21 groups which have been common over all years, are included, together with dummies for years out of school.

${ }^{4}$ Standard errors were clustered at the state level in results available from the author, where results were very similar to those reported here.
} 
control for most of this effect. CPS person-weights were used in calculating the proportions, and cell weights in estimating the regressions, all normalized to sum to one in each year.

Average family income was calculated in year-state-race-education specific cells, using family weights. In 1976, where family weights were missing, all weights were set to one. Here again, all weights were normalized to sum to one in each year. Only families with head of either sex aged 45-54 were used in the calculations, under the assumption that this would be the age group most likely to have teenaged children. For young people $0-5$ years out of school, this variable was lagged three years, under the assumption that this would approximate the time when, on average, individuals would have been most influenced by parental income. For those 6-10 years out of school the variable was lagged eight years, and for those 1115 years out of school, it was lagged thirteen years.

Family income was topcoded to 1975 levels in 2009 dollars $(\$ 204,918)$, since this was the year when CPS topcodes were most restrictive. This involved at the most, 895 families out of 13,341 in 2009 and 844 out of 13,568 in 2010. In all other years it involved less than 500 families, and in most only about 200 families. However, for all topcoded families income was multiplied by a factor of 1.45, following on Blau and Kahn (2007).

Average male wages were calculated at the year-state-race-education-"years out of school" level, using normalized CPS person weights, and calculated as total annual income from wages divided by total hours worked. Hours and weeks worked in the years prior to 1976 were allocated using an algorithm developed by Finis Welch (1979). Individuals were dropped from the analysis if the calculated wage was less than \$2.50 or more than \$250 per hour, in 2009 dollars (again following Blau and Kahn, 2007). The expected hourly wage was used: the estimated wage multiplied by the year-state-race-education-"years out of 
school" specific employment rate, to allow for local unemployment ${ }^{5}$. In matching male wage cells to the female proportions married, a one-year gap was assumed between the ages of males and females, with the males one year older than the females, on average. The male wage was lagged one year to approximate the time of the decision to marry.

Only the average starting wage of women was used in the analysis (the wage of women 0-1 year out of school), because of the potential endogeneity of the female wage. Here again, hours and weeks worked prior to 1976 were allocated using the Welch algorithm, and individuals were dropped from the calculation if the hourly wage was calculated to be less than \$2.50 or greater than \$250 per hour, in 2009 dollars. Normalized CPS person weights were used in the calculation, and the female wage was lagged one year to approximate the timing of a decision to marry.

The "marriage squeeze" variable was calculated as the lag of the ratio of the number of births in year $t$ to the number in year $t-1$ - on the assumption of a one-year difference between men and women at age of marriage. It is used at the national level since local levels could be influenced by migration from state to state in response to economic or marriage market conditions. This is the original version of the variable, used to reflect the imbalance between males and females which would have occurred as a result of the Baby Boom: when cohort size is rising, the older cohorts (the males) would be less numerous than the younger (the females), theoretically putting the women at a disadvantage in the marriage market. The reverse should have been true when cohort size was falling. For those $0-5$ years out of school, a 22-year lag of the variable was used, for those 6-10 years out a 27-year lag, and for those 11-15 years out a 32year lag was used.

\footnotetext{
${ }^{5}$ The results using this expected wage were found to be very similar to those using the observed average wage, however.
} 
Summary statistics for the data used are presented in Table 1. There it can be seen that the steepest declines in proportion married occurred between 1968 and 1990 - the period during which the Baby Boomers were entering these age groups, and their real wages were falling while the income of older families was rising steeply. For all men 0-15 years out of school marriage proportions declined by 30\% in this period, while women's proportion declined by 26\%. For those in the first five years out of school, the declines were $47 \%$ and $40 \%$, respectively.

The models estimated were :

$$
\begin{array}{ll}
\text { Propmar }_{f, k, t}=\beta_{0}+\beta_{1} W_{m, k+1, t-1}+\beta_{2} W_{f, t-1}+\beta_{3} F Y_{t-j}+\mathrm{B}^{\prime} X+u & k=0-15, t=1-42, j=3,8,13 \\
\text { Propmar }_{m, k, t}=\beta_{0}+\beta_{1} W_{m, k, t-1}+\beta_{2} W_{f, t-1}+\beta_{3} F Y_{t-j}+\mathrm{B}^{\prime} X+u & k=0-15, t=1-42, j=3,8,13
\end{array}
$$

where

$$
\begin{aligned}
& \text { propmar }_{f, k, t}=\text { proportion of women who are currently married, } k \text { years out of school, in time } t \\
& \text { propmar }_{m, k, t}=\text { proportion of men who are currently married, } k \text { years out of school, in time } t \\
& W_{m, k+1, t-1}=\text { the average hourly wage of men } k+1 \text { years out of school, at time } t-1 \text {. } \\
& W_{f, t-1}=\text { the average starting wage of women in time } t-1 \text {. } \\
& F Y_{t-j} \quad=\quad \text { average income of families with head of either sex aged 45-54, at time } t-j \text { where } j \text { is } 3
\end{aligned}
$$

Each of the models was disaggregated at the year-state-race-education level, and in addition, two versions of each of the models - with and without the family income variable - were estimated with the "marriage squeeze" variable presented in Figure 6.

\section{Results: Men}

The regression results for men are presented in Table 2, for all variables except the state and "years out of school dummies". It can be seen in Table 2 that the older family income variable has a negative and significant coefficient overall for men 0-15 years out of school, and individually for men 0-5 years and 610 years out of school. It is negative but not quite significant at the 10\% level for men 11-15 years out. As one might expect, the strength of the effect of older family income for men 0-5 years out is two and 
one-half times larger than that for men 6-10 years out, and five times larger than that for men 11-15 years out of school ${ }^{6}$. The unstandardized coefficient for men 0-5 years out indicates an elasticity of 0.33 for the older family income variable ${ }^{7}$. The observed increase in older family income, from 1968 to 2010, of $44.6 \%$ would account for a decline of about $10 \%$ in the proportion married in this group. The actual decline was about $63 \%$, so the rise in older family income would have accounted for about $23 \%$ of the observed decline in the proportion married among men 0-5 years out of school, between 1968 and 2010.

The male wage is estimated to have the expected positive effect on proportion married. Its coefficient is highly significant for all groups, regardless of years out of school, with an elasticity of 0.18 for men 0-5 years out of school, 0.14 for men 6-10 years out, and 0.11 for men $11-15$ years out.

Women's starting wage, too, is highly significant, but its effect changes over groups and over time. For men 0-5 years out of school, women's wage has had a positive effect throughout most of the study period, but the effect has been declining over time, and turned negative around 2004. For men 6-10 and 11-15 years out of school, however, the effect started out negative, and has gradually turned positive, as predicted by Oppenheimer (1988). For men in both groups, the effect would have turned positive at the end of the 1990s - at the same time that the effect of women's starting wage on fertility would have turned positive for these groups, as estimated in Macunovich (2011). Women's higher earning power appears to have begun to make them more attractive marriage partners.

The "marriage squeeze" variable is problematic, however. Its predicted sign according to theory is negative, since an oversupply of young men relative to women should make it harder for young men to find marriage partners. But the effect estimated here is positive for all groups - and highly significant for

\footnotetext{
${ }^{6}$ As indicated by non-standardized coefficients - results available on request.

${ }^{7}$ Results available on request.
} 
the younger groups ${ }^{8}$. The estimated effect for men 6-10 years out of school is about two-thirds that for young men 0-5 years out, and the effect for men 11-15 years out is about one-third. But all estimated effects are positive, so it's difficult to say what exactly is being measured. This is similar to the finding in Angrist (2002), where there was no explanation, either.

In terms of the other control variables, there is a large and highly significant negative time trend regardless of the model estimated, reflecting the many changes which have occurred socially that have affected marriage patterns, especially the trend toward cohabitation. The coefficient for black males is negative and highly significant for all groups. The coefficient for other racial groups is also negative, except for the 11-15 group, where it is insignificantly positive. The coefficients on the schooling dummies are strongly negative for those with less than twelve years of schooling, except for those with less than eight years of schooling 11-15 years out of school, where the effect is weakly positive. The effect of higher levels of education - especially for those with more than sixteen years of education - is strongly positive for all groups. This is consistent with the curves in Figure 1, which show the highest proportions married among those with more than sixteen years of schooling.

\section{Results: Women}

Table 3 corresponds to Table 2, but presents results for women, again not displaying effects of the state and "years out of school" dummies. As for men, the coefficient on the older family income variable is highly significant overall for women 0-15 years out of school, and individually for women 0-5 years out. But unlike the result for men, here the coefficient is not significant - although negative - for women 6-10 years out of school. But as for men, it is also not significant - although negative - for women 11-15 years out. Thus the effect here is really just for women $0-5$ years out of school: an effect which no doubt then carries through into proportions married in older age groups. In standardized form the coefficient is the

\footnotetext{
${ }^{8}$ The overall R-square increases markedly when it is entered in the equation, because it is a simple time series variable with very small variance.
} 
same size as that for the female wage - although opposite in sign - and three times as large as the coefficient on the male wage. The elasticity for women 0-15 years out of school is less than that for men - just -0.21 - so that with a 44.6\% increase in older family income between 1968 and 2010, it would have accounted for a drop of about $6.5 \%$ in the proportion married in this group. The actual decline in proportion married in this group between 1968 and 2010 was 58\%, so older family income would have accounted for about $16 \%$ of the decline, for women, as compared to $23 \%$ for men.

The effect of the male wage for women's proportion married, although positive and highly significant, is much smaller than its effect on male proportions married. The standardized coefficient for women is constant over all three groups, but only about one-third as large as that for men 0-5 years out of school, and only about one-seventh as strong as that for the older men. The elasticity of the response to the male wage is only about 0.04 for women $0-5$ years out of school, and 0.01 for the older women.

Here again, as with the men, the effect of the female starting wage is very nuanced. Its effect is highly significant statistically, but it varies over time, and between the younger and older women. For younger women the base effect is positive, with a negative time trend, but for older women it is negative, with a positive time trend. For the younger women the effect has been positive throughout the study period, only turning negative about now. For older women, the turnaround from negative to positive would have occurred in the late 1990s. This is the same turnaround point as that estimated for the effect of the female wage on men's proportion married, and also for fertility, as estimated in Macunovich (2011). Here again, the suggestion is that over time women's higher wage has begun to make them more attractive marriage partners, as suggested by Oppenheimer (1988). Unfortunately for the proportion married, however, the average female starting wage actually declined between 2000 and 2010, as shown in Figure 4 and in Table 1. 
The effect of the "marriage squeeze" variable is positive and significant, as hypothesized by the theory, overall and for women 0-5 and 6-10 years out of school. For women 11-15 years out it is negative but not significant. The positive effect is the same as that found by Angrist (2002), for women's propensity to marry. It suggests that when there is a surplus of men relative to women, it will be easier for a woman to find an appropriate partner. Unfortunately it is difficult to maintain this interpretation, however, since the estimated effect on men is also positive.

The effect of the other control variables is similar to that seen for men's proportion married. Again there is a large and highly significant negative time trend, reflecting at least in part the trend toward cohabitation. The standardized coefficient on the Black indicator variable is negative and much larger than for any other variable, and very highly significant statistically. The effect for other non-white races is negative and significant - although much smaller in magnitude - overall and for the younger women, but positive and not significant for the older women. The effect for those with 8-11 years of schooling is large, negative and highly significant, whereas for those with sixteen or more years of education it is large, positive and highly significant. However, the positive effect for older women with more than sixteen years of schooling is only about half as strong as that for men with the same years out of school.

\section{Summary}

Richard Easterlin in 1978 hypothesized that young people's tendency to marry would be positively influenced by patterns of male relative income - the earning potential of young males relative to their aspirations, with their aspirations a direct function of their parents' income when they were growing up. This relative income was hypothesized to be, in turn, a negative function of the young people's relative cohort size - the size of their own birth cohort relative to that of their parents' cohort. This was hypothesized to be due to imperfect substitutability between experience groups in the labor market, with an oversupply of young workers pushing down their wages relative to those of older workers - their own fathers, in effect. 
There have been only two studies that have tested this relationship between relative income and marriage directly - that is, using older family income: MacDonald and Rindfuss (1981) and Macunovich (2002), with the first finding no support for the theory, and the second finding strong support. Other studies have looked at the effect indirectly - using parental education and/or occupation as proxies for income. These have found mixed effects, although in general the effects of higher levels of education and occupation for the parents have tended to be associated with lower propensities to marry.

Macunovich (1999) found support for the relationship between male relative wages and relative cohort size - with relative wages measured as the hourly earnings of young men relative to the hourly earnings of males with 25-34 years of work experience. Easterlin's theory of imperfect substitutability in the labor market appears to hold true. But the Easterlin theory hypothesizes that the relationship with marriage patterns depends on male relative income - the earning potential of young people relative to older family income - and Figures 7 and 8 show that the relationship between this measure, and relative cohort size, has not held up since 1990, despite strong increases in real wages as shown in Figures 3 and 4. Figure 5 illustrates why this is the case: increasing female labor force participation among older familes. Twoearner families have pushed up family income relative to the earnings of the father alone. This increasing female labor force participation, however, has been shown to be a function of relative cohort size, as well, with younger women in the 1970s and 1980s entering the labor force to supplement the falling earnings of young men (McNown and Rajbhandary, 2003; Macunovich 1996), producing older two earner families in the last two decades. Thus what we have been observing has indeed all been a function of relative cohort size - but the relationship is more complex than was originally hypothesized, due to the labor force behavior of young mothers.

This study, then, looks directly at the effect of relative income on marriage patterns, rather than at the effect of relative cohort size, since relative income is assumed to be the proximate determinant of young 
people's decision to marry. But such an analysis is made difficult by the fact that data on parental income is not collected in available data sets for the U.S ${ }^{9}$. So this study has approximated the relationship between young people and older family income by using more aggregated data - looking at young people in year-state-race-education-"years out of school" specific cells, and assuming that the behavior in these cells would be related to older family income in corresponding year-state-race-education specific cells. And instead of looking just at the youngest cohort of individuals - those just, say, 0-5 years out of school - this study has examined behavior in the entire group 0-15 years out of school, to trace longer-term effects of parental income.

The dependent variables in the analysis have been the proportions of men and women currently married, who are 0-5, 6-10 and 11-15 years out of school. Older family income has been lagged appropriately to approximate that variable when the young people were still living in their parents' homes. Older family income has been found to have a strong negative effect on marriage among men at all three levels of years out of school, although the effect diminished with increasing years. It is two and one-half times larger for men 0-5 years out, than for men 6-10 years out, and five times larger than for men 11-15 years out. ${ }^{10}$. The estimated coefficient for men $0-5$ years out indicates an elasticity of -0.33 for the older family income variable. The observed increase in older family income, from 1968 to 2010, of 30.4\% would account for a decline of about $10 \%$ in the proportion married in this group. The actual decline was about $63 \%$, so the rise in older family income would have accounted for about $16 \%$ of the observed decline in the proportion married among men 0-5 years out of school, between 1968 and 2010.

For young women, the effect of older family income has been found to be negative and highly significant for women 0-15 years out of school overall, and for women 0-5 years out specifically, but the effect on

\footnotetext{
${ }^{9}$ An exception is the General Social Survey, which contains a categorical variable estimating whether the parental income when the respondent was 16 was "far below, below, average, above, or far above" average income. This variable may, however, be influenced by the respondent's own estimation of what was "average".

${ }^{10}$ As indicated by non-standardized coefficients - results available on request.
} 
women 6-15 years out of school, while negative, is not statistically significant. Thus its primary effect throughout the 0-15 year period has been on young men's propensity to marry. The elasticity of the proportion married with respect to older family income was found to be -0.21 , suggesting that the observed increase in older family income would have accounted for $11 \%$ of the observed decline in the proportion of young women who are married, during the study period.

Consistent with the literature, the male wage has been found to exert a very significant positive effect on proportions married throughout the fifteen year period, for both men and women. For men the strength of the effect increases with years out of school, with older men's being twice that of men 0-5 years out of school. For women, however, the strength remains relatively constant over the fifteen year period. The pattern of the wage is shown in Figure 3.

The effect of women's starting wage on patterns of marriage has been more nuanced, however. Only the starting wage has been used in the analyses, because of the potential endogeneity of women's wages. For both men and women, the effect varies significantly over time, with an initial negative effect for women 6-15 years out of school that became positive in the late 1990s. For women 0-5 years out, however, the effect has been positive throughout the study period, but has recently turned mildly negative. These findings are consistent with those of Qian and Preston (1993) and Sweeney (1999). The basic and emerging positive effect is consistent with Oppenheimer's (1988) theory that women have become more attractive potential marriage partners, as their wage has risen. The pattern of the female starting wage is presented in Figure 4.

And finally, a "marriage squeeze" variable was tested for its effect on proportions married, with mixed results. In theory, an excess of males to females of marriageable age (the sex ratio) will be advantageous for women's chances of marrying, but disadvantageous for men. The results here support the former, but 
not the latter, portion of the theory, since the variable was found to have a very significant positive effect on the proportions married of both men and women. This result is in accord with Angrist(2002).

Thus the results presented in this analysis support Richard Easterlin's relative income hypothesis with regard to young people's propensity to marry. The effect of older family income has accounted for only $16 \%$ of the observed decline in men's proportion married, and $11 \%$ of women's, however, with the bulk of the decline attributable to other factors such as the sharp increase in cohabitation during the study period. 


\section{Bibliography}

Ahlburg, Dennis A. (1984). "Commodity Aspirations in Easterlin's Relative Income Theory of Fertility," Social Biology, 31(3/4):201-207 (Fall).

Angrist, J (2002). How Do Sex Ratios Affect Marriage and Labor Markets? Evidence from America's Second Generation, The Quarterly Journal of Economics 117(3): 997-1038.

Blau, FD and LM Kahn (2000). Understanding Young Women's Marriage Decisions: The Role of Labor and Marriage Market Conditions, Industrial and Labor Relations Review 53(4):624-647.

Blau, Francine and LM Kahn (2007). "Changes in labor supply behavior of married women 1980-2000", Journal of Labor Economics, 25(31):393-438.

Burgess, S and C Propper (2003). The Role of Income in Marriage and Divorce Transitions among Young Americans, Journal of Population Economics 16(3):455-475.

Cooney, TM and DP Hogan (1991). Family-Building Patterns of Professional Women: A Comparison of Lawyers, Physicians, and Postsecondary Teachers, Journal of Marriage and the Family 51:74958.

Easterlin, RA (1961). The Baby Boom in Historical Perspective, American Economic Review, 51(5):869911.

Easterlin, RA (1978). What Will 1984 Be Like? Socioeconomic Implications of Recent Twists in Age Structure@, Demography, 15(4 Nov): 397-432.

Goldscheider, FK and LJ Waite (1986). Sex Differences in the Entry Into Marriage, American Journal of Sociology 92:91-109.

Gould, E and D Paserman (2003). "Waiting for Mr. Right", Journal of Urban Economics 53(2):257-281.

Grossbard-Shechtman, S (1984). A Theory of Time in Markets for Labour and Marriage, Economic Journal, 94(376), 863-882.

Grossbard-Shechtman, S (1985). Marriage Squeezes and the Marriage Market, in Kingsley Davis and Amyra Grossbard-Shechtman, eds., Contemporary Marriage: Comparative Perspectives on a Changing Institution. New York: Russell Sage Publications.

Guttentag, M, and PF Secord (1983). Too Many Women? The Sex Ratio Question. Beverly Hills, CA: Sage Publications.

Lloyd, KM and SJ South (1996). Contextual Influences on Young Men's Transition to First Marriage, Social Forces 74:1097-1119.

Loughran, DS (2002).The Effect of Male Wage Inequality on Female Age at First Marriage, Demography 84(2):237-250. 
MacDonald, MM and RR Rindfuss (1978). "Relative Economic Status and Fertility: Evidence from a Cross-section," in Research in Population Economics, Vol. 1, Julian Simon, ed., JAI Press:Greenwich, CT.

MacDonald MM and RR Rindfuss (1981). Earnings, Relative Income, and Family Formation, Demography 18:123-136.

Macunovich, DJ (1996). Relative Income and Price of Time: Exploring Their Effects on U.S. Fertility and Female Labor Force Participation, in Fertility in the United States: New Patterns, New Theories, Population and Development Review, supplement to Volume 22(1996):223-257.

Macunovich, DJ (2002). Birth Quake: The Baby Boom and Its Aftershocks. University of Chicago Press, Chicago.

Macunovich, DJ (2011). Revisiting the Easterlin Hypothesis: U.S. Fertility 1968-2010, IZA Discussion Paper \#.

McNown, R and S Rajbhandary (2003). Time Series Analysis of Fertility and Female Labor Force Behavior, Journal of Population Economics, 16:501-523.

McLanahan S, L Casper (1995). Growing Diversity and Inequality in the American Family. In State of the Union: America in the 1990s, ed. Reynolds Farley, 2:1-45. New York: Russell Sage Foundation.

Oppenheimer, VK (1988). A Theory of Marriage Timing, American Journal of Sociology, 94(3): 563591.

Oppenheimer, VK (1997). Women's Employment and the Gains to Marriage: The Specialization and Trading Model of Marriage, Annual Review of Sociology 23:431-53.

Oppenheimer, VK, M Kalmijn, and N Lim (1997). Men's Career Development and Marriage Timing During a Period of Rising Inequality, Demography 34:311-30.

Pollard MS and Z Wu (1998). Divergence of Marriage Patterns in Quebec and Elsewhere in Canada, Population and Development Review 24(2):329-356.

Qian, Z, SH Preston SH (1993). Changes in American Marriage, 1972 to 1987: Availability and Forces of Attraction by Age and Education, American Sociological Review 58:482-95

Sassler, S and R Schoeni (1999). The Effect of Attitudes and Economic Activity on Marriage, Journal of Marriage and the Family 61:147-59.

Smock, PJ and WD Manning (1997). Cohabiting Partners' Economic Circumstances and Marriage, Demography 34(3):331-341.

Sweeney MM (2002). Two Decades of Family Change: The Shifting Economic Foundations of Marriage, American Sociological Review 67(1): 132-147.

Teachman, JD, KA Polonko, and GK Leigh (1987). Marital Timing: Race and Sex Comparisons." Social Forces 66:239-68. 
U.S. Department of Commerce, Bureau of the Census (2010). "Current Population Survey, March Supplement", as prepared by the Unicon Corporation in CPS Utilities.

Waite, LJ and G Spize (1981). Young Women's Transition to Marriage, Demography 18(4):681-694.

Watson, T and S McLanahan (2009). Marriage Meets the Joneses: Relative Income, Identity and Marital Status, NBER 14773.

Welch F (1979) Effects of Cohort Size on Earnings: the Baby Boom Babies= Financial Bust. Journal of Political Economy 87(5,pt.2):S65-S97.

Xi, Y, JM Raymo, K Goyette and A Thornton (2003). Economic Potential and Entry into Marriage and Cohabitation, Demography 40(2):351-367. 
Fig 1. Men 0-15 Years Out of School: Proportions Married by years of schooling

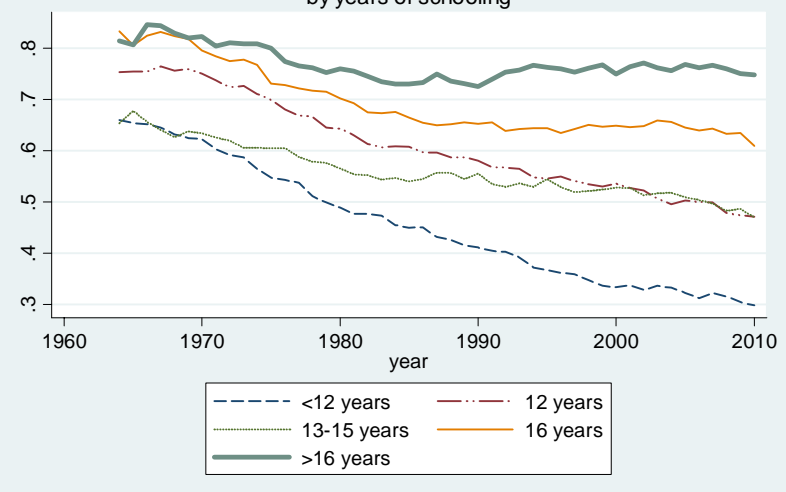

Fig 3. Average Wage: Men in 0-15 Years Out of School

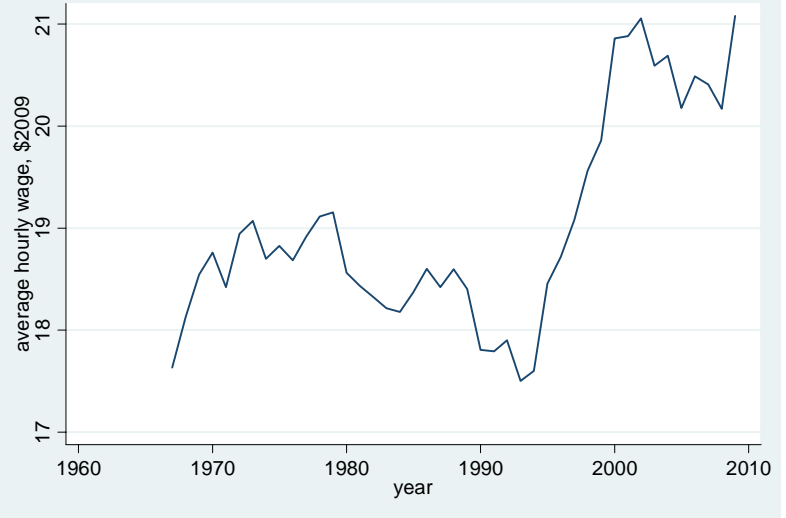

Fig 5. Comparison of Fathers' and Families' Income

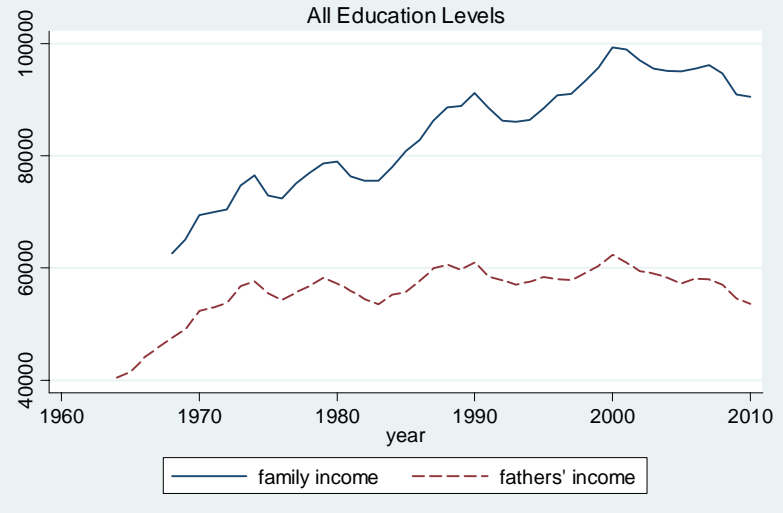

Fig 2. Women 0-15 Years Out of School: Proportions Married by years of schooling

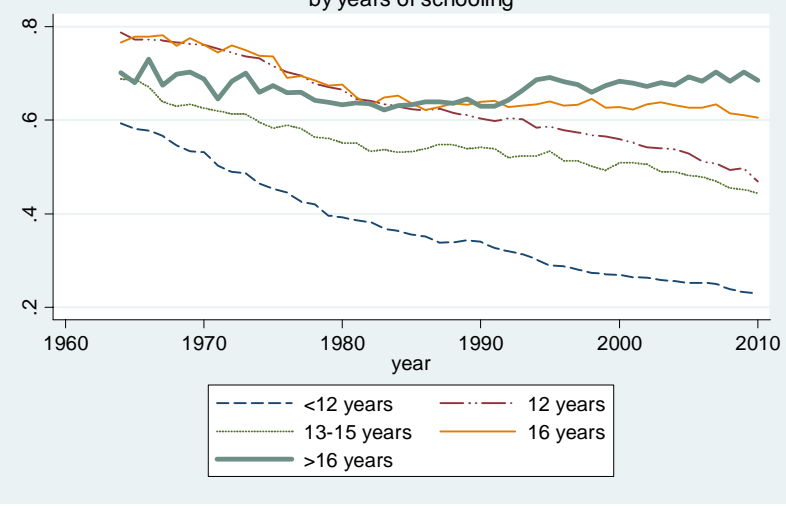

Fig 4. Average Starting Wage for Women

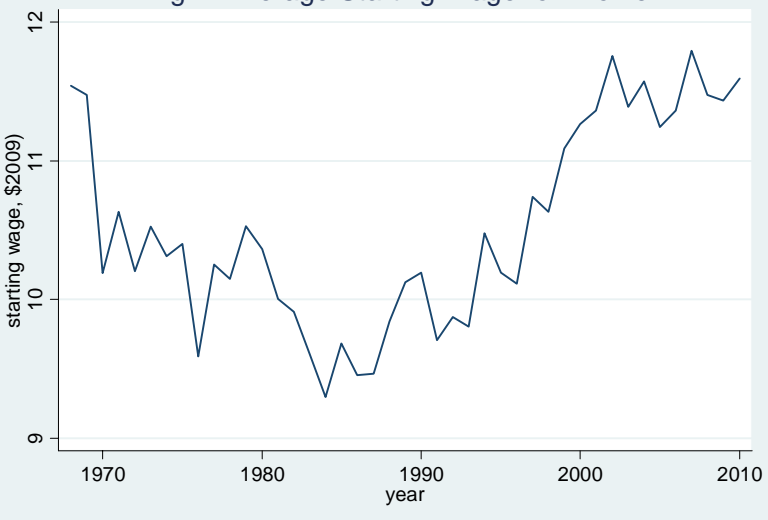

Fig 6. U.S. Marriage Squeeze Variable for those $0-5$ years out of school

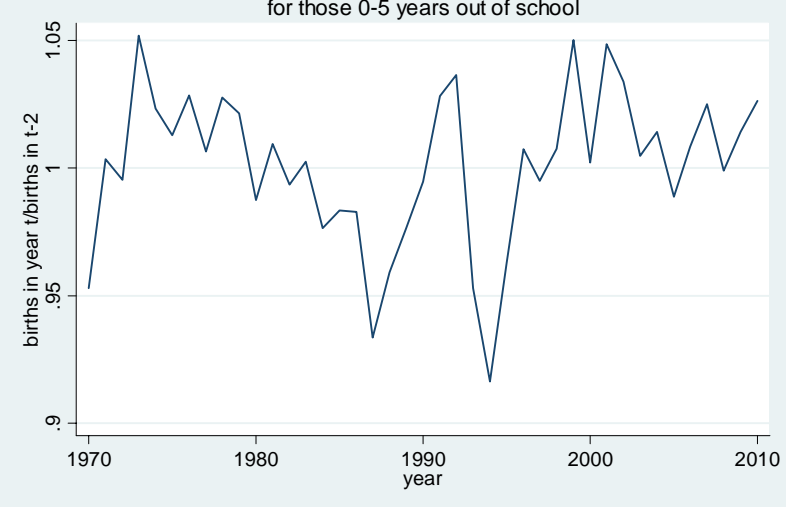



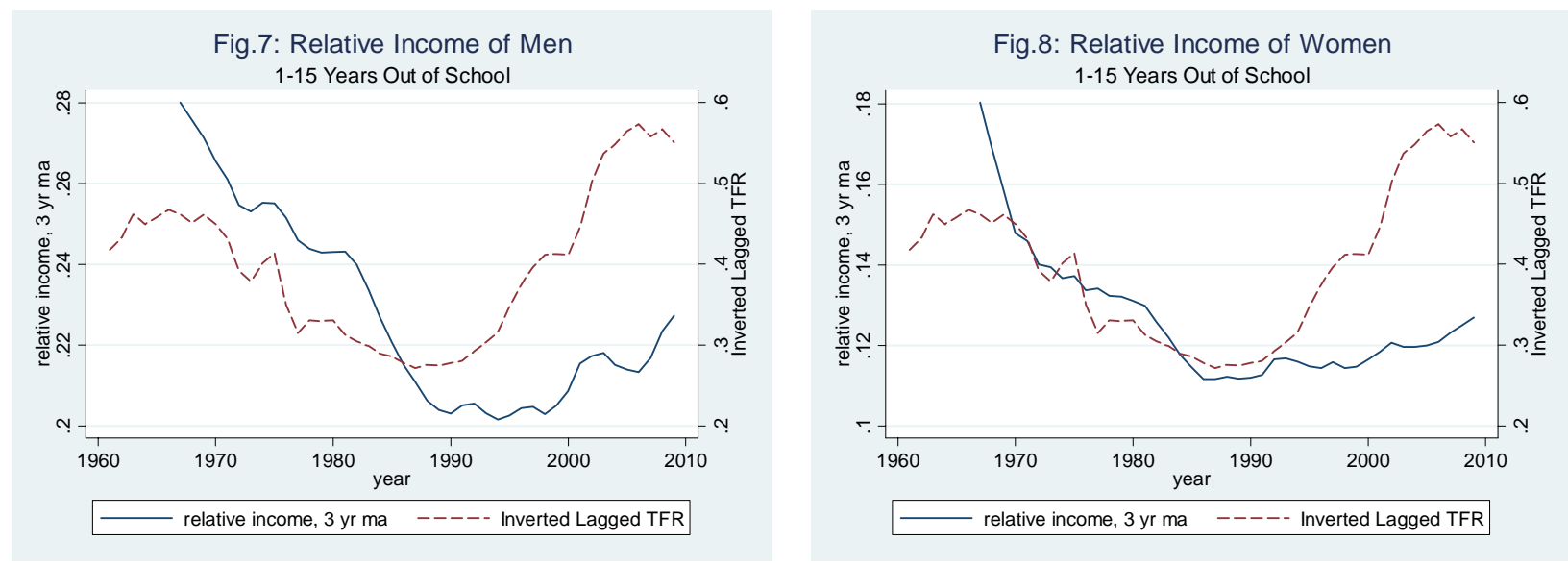
Table 1: Summary Statistics (unweighted, and not using moving averages)

\begin{tabular}{|l|l|l|l|l|l|}
\hline \multicolumn{2}{|c|}{} & 1968 & 1990 & 2000 & 2010 \\
\hline \multicolumn{2}{|l|}{ Proportion married by years out of school: } \\
\hline Men & $0-5$ & $.34(.38)$ & $.18(.31)$ & $.16(.31)$ & $.13(.29)$ \\
\hline & $6-10$ & $.76(.33)$ & $.51(.39)$ & $.49(.40)$ & $.43(.40)$ \\
\hline & $11-15$ & $.85(.28)$ & $.65(.36)$ & $.63(.39)$ & $.59(.39)$ \\
\hline & all & $.61(.41)$ & $.43(.41)$ & $.40(.42)$ & $.37(.41)$ \\
\hline
\end{tabular}

Women

\begin{tabular}{|l|l|l|l|l|l|}
\hline & $0-5$ & $.45(.39)$ & $.27(.36)$ & $.25(.36)$ & $.21(.33)$ \\
\hline & $6-10$ & $.77(.33)$ & $.57(.39)$ & $.55(.40)$ & $.50(.40)$ \\
\hline & $11-15$ & $.81(.31)$ & $.64(.37)$ & $.63(.39)$ & $.59(.39)$ \\
\hline & all & $.65(.39)$ & $.48(.41)$ & $.45(.42)$ & $.42(.41)$ \\
\hline
\end{tabular}

Male wage by years out of school:

\begin{tabular}{|l|l|c|c|c|c|}
\hline & $0-5$ & $15.3(8.4)$ & $14.7(10.0)$ & $15.7(11.8)$ & $17.4(15.4)$ \\
\hline & $6-10$ & $18.3(7.5)$ & $19.0(10.7)$ & $21.0(14.3)$ & $21.9(16.5)$ \\
\hline & $11-15$ & $19.9(10.2)$ & $21.9(11.4)$ & $23.6(16.5)$ & $26.2(21.9)$ \\
\hline & all & $17.6(9.0)$ & $18.3(11.1)$ & $19.9(14.6)$ & $21.7(18.5)$ \\
\hline
\end{tabular}

Female starting wage by years of schooling:

\begin{tabular}{|l|l|c|c|c|c|}
\hline & $<12$ & $9.0(5.6)$ & $8.2(6.7)$ & $11.7(13.0)$ & $10.1(7.6)$ \\
\hline & 12 & $9.8(3.5)$ & $9.4(6.2)$ & $10.4(8.0)$ & $8.9(3.5)$ \\
\hline & $>12$ & $14.9(10.0)$ & $12.9(11.3)$ & $16.2(16.7)$ & $15.5(12.6)$ \\
\hline & all & $12.0(8.2)$ & $10.9(9.5)$ & $13.7(14.4)$ & $12.9(10.7)$ \\
\hline
\end{tabular}

Older family income by years of schooling (000's):

\begin{tabular}{|l|l|c|c|c|c|}
\hline & $<12$ & $42.2(14.7)$ & $47.7(25.4)$ & $42.4(22.0)$ & $39.9(21.8)$ \\
\hline & 12 & $57.0(18.0)$ & $70.7(24.2)$ & $65.6(23.4)$ & $62.8(23.3)$ \\
\hline & $>12$ & $82.2(29.4)$ & $108.7(44.8)$ & $113.7(46.8)$ & $104.7(51.0)$ \\
\hline & all & $62.1(29.0)$ & $81.5(45.2)$ & $86.1(49.1)$ & $81.0(49.6)$ \\
\hline
\end{tabular}

Standard deviations in parentheses. 


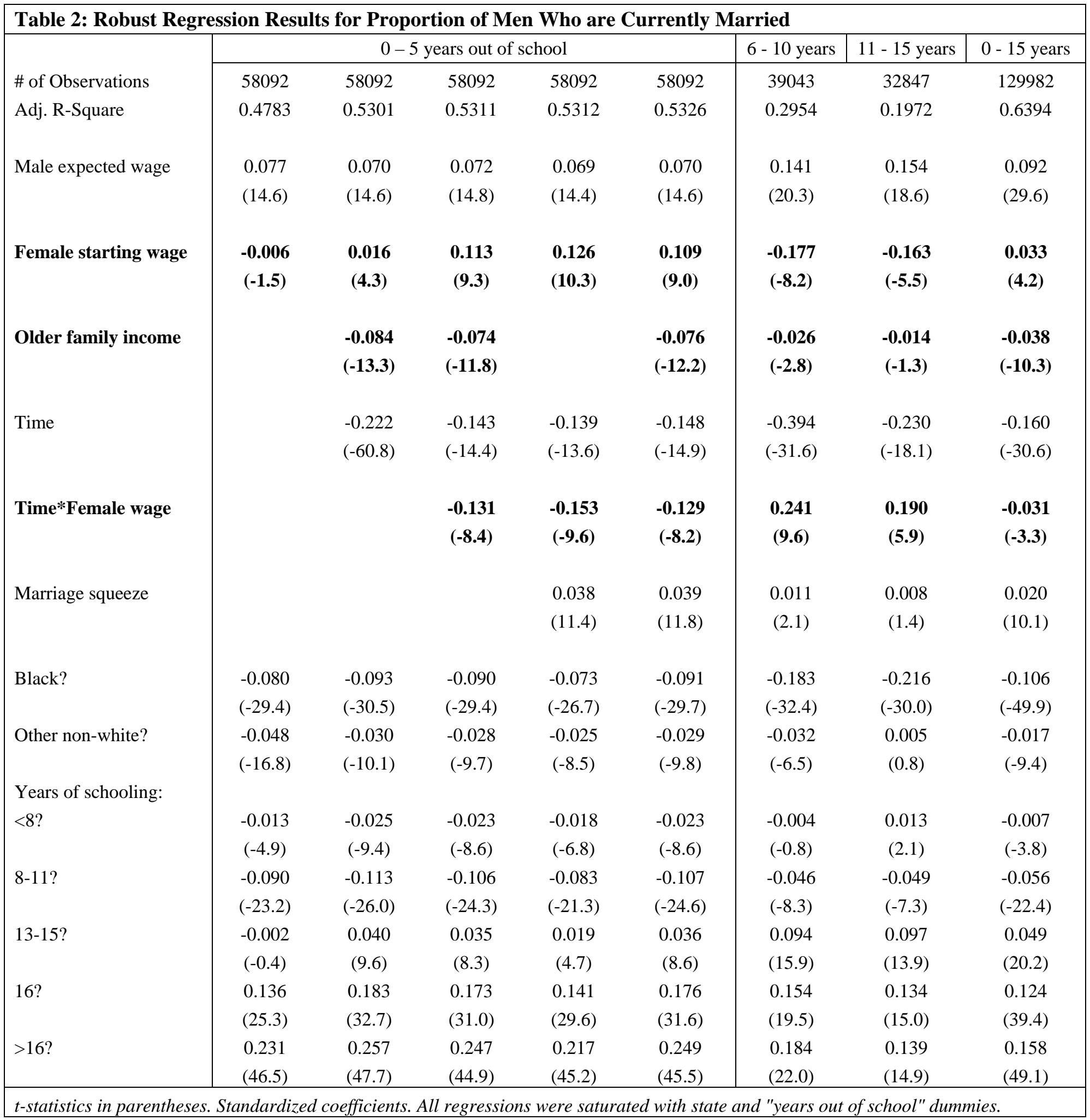




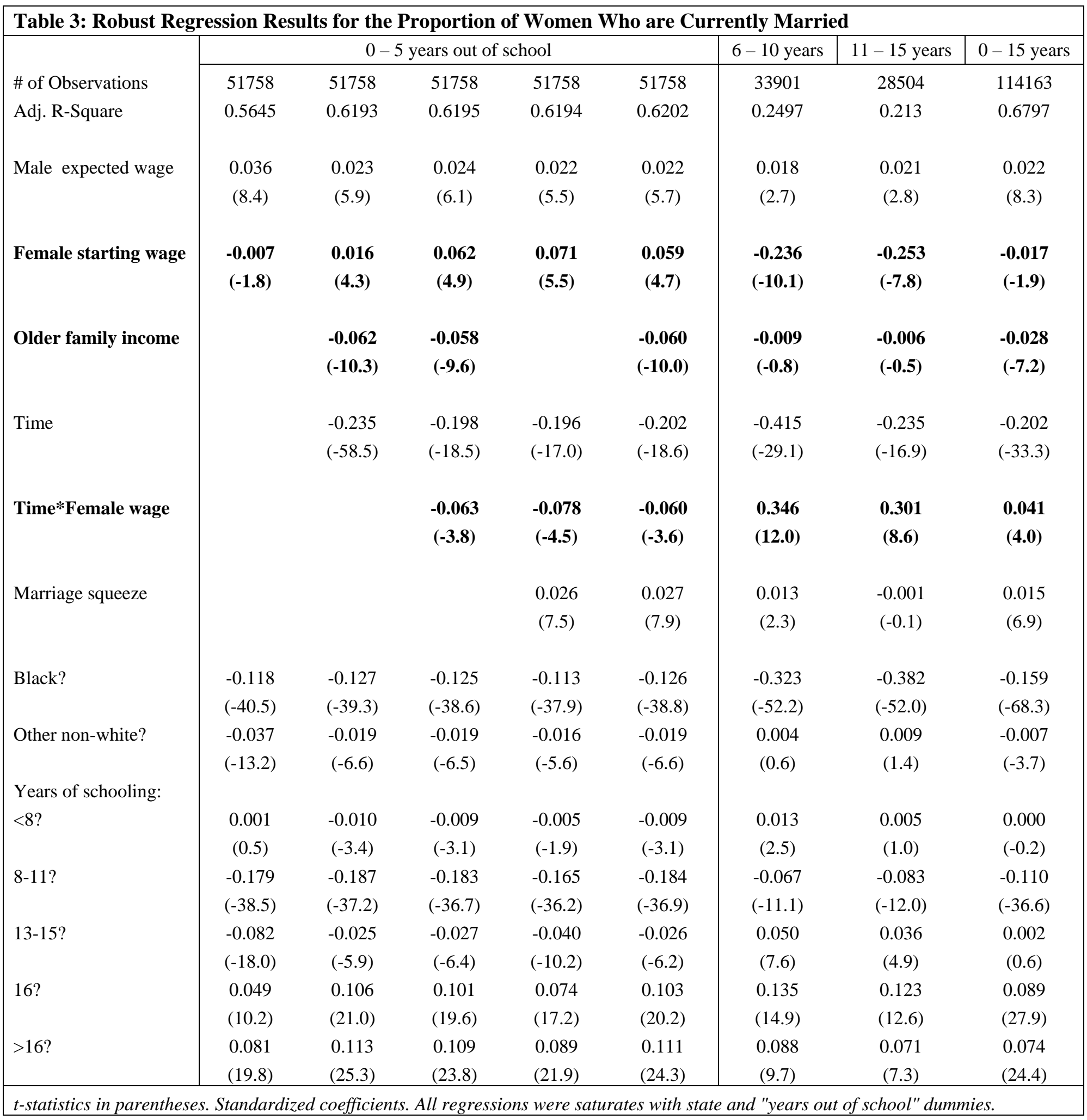

